\title{
Japanese Fairy Tales and Ideology: A Case Study on Two Fairy Tales with Female Main Character
}

\author{
Fajria Noviana \\ \{ fajria.noviana@live.undip.ac.id \} \\ Faculty of Humanities, Diponegoro University, Indonesia
}

\begin{abstract}
Gramsci states that literature is an ideological site. Thus, the literary work of a nation can represents the nation's ideological view, as well as Japanese. Therefore, this paper discusses the ideology of the Japanese as a nation which deals with women, which analyzed through fairy tales as part of Japanese classical literary work. With content analysis method, the purpose was to identify and make ideological categorization that contained in two Japanese fairy tales with female main character, namely Kaguyahime and Tsuru no Ongaeshi. Meanwhile, to identify the ideology contained in these tales are based on Gramsci's theory of ideology and Williams' ideological categorization. The results are: 1) patriarchy ideology and feminism are found in these two tales; 2) the existence of hegemonic ideologies related to patriarchism and gender, residual ideology found in the form of patriarchism, and emergent ideology found in the form of feminism in both tales.
\end{abstract}

Keywords: Japanese fairy tales, ideology, patriarchy, hegemony, Gramsci

\section{Introduction}

In daily lives, we will never be separated from storytelling activities as part of a community group, both real or fictional stories. News broadcasts on television and radio are examples of real stories, while fables and legends are examples of fictitious stories. According to Collingwood [1], story that belong to some community group can be called a fairy tale if it meets the following two criteria:

a. When viewed in terms of its shape, it is a traditional story that is told from generation to generation.

b. When viewed in terms of its contents, it is a story that has a magical element.

Tales that are part of oral literature have been inherent in the lives of various groups of people in various nations. It can be said that each nation must have its own fairy tale. For examples, there are Kancil tale from Java, Malin Kundang from Sumatra, Cinderella from Germany, Pinocchio from Italy, Gulliver from England, 1001 Nights from the Middle East, Urashimatarou from Japan, and others. All these tales are usually told by parents to their children when they were kids. Then when those kids grow up and became parents, they tell their children those fairy tales and so on for generations.

As a traditional story that is told from generation to generation, fairy tales are able to absorb aspects of life found in the supporting community groups, both in the form of social problems, ethics, and others. According to what was stated by Ratna [2] regarding the reasons for the association of 
literary works with the community, then the research of a literary work cannot be separated from the supporting community groups.

Tales as part of oral literature written down through generations contain complex cultural aspects, which have close links with the supporting community groups, including women. In various nations of the world, women are usually in a position (or positioned) lower than men. In a world that tends to be patriarchal, men are positioned more dominantly than women. Women in this case refer to sex, while femininity which is generally owned by women refers to gender. In its relation to patriarchy, Millet assumed patriarchy operated through ideology, institutions, and coercion of power [3].

Gramsci states that literature is an ideological site [4]. Thus, the literary work of a nation can represents the nation's ideological view. Therefore, the ideology of the Japanese nation, especially those related to women, is presented in this paper as a result of the analysis of Japanese fairy tales as part of its classical literary work. The fairy tale that is used as data source of this research are two fairy tales that has female lead character called Kaguyahime or "Princess Kaguya" and Tsuru no Ongaeshi or "The Crane's Return", which written in Heian Period (794-1185). The purpose of this study was to identify the ideology and to make categorizations of ideology contained in these two Japanese fairy tales, which still widely tell.

As for state of the art of this study, the following tables explains three journal articles that related to ideology in literary works and Japanese folklore.

Table 1. Comparison of research I

\begin{tabular}{ll}
\hline \multicolumn{1}{c}{ Article title } & Ideologi dalam Novel Pabrik Karya Putu Wijaya \\
\hline $\begin{array}{l}\text { Author } \\
\text { Journal name (year) }\end{array}$ & $\begin{array}{l}\text { Ahmad Zamzuri } \\
\text { Atavisme (2017) } \\
\text { Related variables }\end{array}$ \\
$\begin{array}{l}\text { Findings } \\
\text { Ideology, hegemony, subaltern, dominant }\end{array}$ & $\begin{array}{l}\text { There are four ideologies in this novel, namely the ideology of authoritarianism, } \\
\text { individualism, liberalism, and anarchism } \\
\text { 2. }\end{array}$ \\
& $\begin{array}{l}\text { The ideological formation emerged in three relations, namely the contradictory } \\
\text { relationship between authoritarianism and democratic ideology, correlative }\end{array}$ \\
& relations between the ideologies of liberalism and hedonism, and subordinate \\
Ideology in literary work & Data source \\
Similarity &
\end{tabular}

Table 2. Comparison of research II

\begin{tabular}{|c|c|}
\hline Article title & $\begin{array}{l}\text { Identifikasi Ideologi dan Pola Relasinya dalam Novel-novel Jacqueline } \\
\text { Woodson }\end{array}$ \\
\hline Author & Muhammad Al Hafizh \\
\hline Journal name (year) & Atavisme (2016) \\
\hline Related variables & Ideology, hegemony, identification, pattern of relation \\
\hline Findings & $\begin{array}{l}\text { 1. The ideology involved in racial differences in Woodson's novels is the } \\
\text { ideology of liberalism, capitalism and racism } \\
\text { The pattern of relations between ideologies shows that the ideology of liberalism is a } \\
\text { hegemonic ideology, while capitalism is an emergent ideology, and racism is a } \\
\text { residual ideology [6] }\end{array}$ \\
\hline Similarity & 2. Ideology and correlation between ideologies in literary works \\
\hline Difference & Data source \\
\hline
\end{tabular}


Table 3. Comparison of research III

\begin{tabular}{ll}
\hline Article title & Representasi Gender dalam Folklor Jepang \\
\hline Author & Nina Alia Ariefa, Mutiawanthi \\
Journal name (year) & Al Azhar Indonesia Seri Humaniora (2017) \\
Related variables & Gender, representation, Japanese folklore \\
Findings & $\begin{array}{l}\text { There are depictions of different representations between female figures and male } \\
\text { figures regarding gender issues that include differences in activity space, character } \\
\text { depiction, and roles/responsibilities [7] }\end{array}$ \\
Similarity & Japanese folklore Kaguyahime and Tsuru no Ongaeshi as data source \\
Difference & Research object \\
\hline
\end{tabular}

Theory used in this study is the theory of sociology of literature. In general, the sociology of literature can be defined as the study of the relationship between literary work and society. Damono suggested several opinions regarding various approaches to literary works, one of which was sociology. From Wellek and Warren, Damono found at least three different types of approaches in literary sociology [8], namely:

a. Sociology where the author defeats social status, social ideology, and others that concern authors as producers of literature

b. Sociology of literary works that defines the literature itself

c. Sociology of literature that defines the reader and the social influence of literature

The third point in the approach above is then used as the basis for the use of the sociology approach in this study. This is considering that the ideology analyzed in this study is the ideology contained in literary work and its influence in the society of readers of the literary work.

Related to Gramsci's statement that literature is an ideological site in the previous paragraph, Zamzuri in his writing states that:

"Sebagai sebuah situs ideologi, karya sastra tidak hanya menjadi arena pertarungan ideologi, tetapi juga berperan sebagai alat pemersatu antara kekuatan-kekuatan sosial yang sesungguhnya bertentangan. Pada saat bersamaan pula, karya sastra menjadi ajang pertarungan tindakan kolektif kelompok subordinat (subaltern) untuk melakukan counter hegemoni. Dalam situasi seperti itu, karya sastra akan mengandung ideologi-ideologi, baik bersifat bertentangan, korelatif, maupun subordinatif." [5]

According to Gramsci, Buttigieg divided ideology into three levels. The first ideological level is philosophy, which is only owned by the dominant class. This became the most developed form of ideology, because it was able to make the notion of domination rooted in society. The second level of ideology is ideas that are too complex to be digested by subaltern social strata. An example is neoliberalism which is then simplified into the discourse of freedom of expression, freedom of trade, and so on. Finally, according to Gramsci, the third level of ideology is common sense which is the result of various forms of dominant dissemination of philosophy and ideology through soap operas on television, film, music, propaganda, etc. [9]. Therefore, common sense is a crucial area for ideological conflict. This is confirmed by the existence of statements about common sense as the domain of practical awareness which is a guideline for all actions, so there is no doubt that common sense is the most significant prone area of ideological conflict [10].

The third level of ideology according to Gramsci is the closest level to the community. As stated by Millet [3] that ideology is one of the operational means of patriarchism, this article discusses the ideology contained in the Japanese fairy tale as a nation that commonly considered patriarchal. 


\section{Method}

This research type is qualitative descriptive research which data taken from various kinds of written sources related to the ideology contained in the literary works. Those data are then classified according to the characteristics of an ideology to draw conclusions. The research population is classic Japanese tales. The purposive sampling technique was used to determine the research sample which included two classic Japanese tales with female main characters who are still widely spoken, to find out what ideologies are contained in classic Japanese fairy tales that have female main characters. The two fairy tales are Kaguyahime and Tsuru no Ongaeshi. This study uses primary data and secondary data which is collected by literature studies. Primary data obtained from Japanese fairy tales titled Kaguyahime and Tsuru no Ongaeshi. Meanwhile, data from various printed books and journals, e-books and online journals are treated as secondary data. Data from both fairy tales about the characters that appear in the story, background, and things related to the mindset and habits obtained by close reading.

In addition to mindset and habits, the analysis of ideological identification was carried out by close reading of these fairy tales to find traits or values that represent an ideology based on Gramsci's perspective, which is contained in various events that occur in these fairy tales. This is in line with Thompson's statement below regarding language in the social sphere as a mean to analyze ideology.

"Hence to study ideology is, in some part and in some way, to study language in the social world. It is to study the ways in which language is used in everyday social life, from the most mundane encounter between friends and family members to the most privileged forums of political debate. It is to study the ways in which the multifarious uses of language intersect with power, nourishing it, sustaining it, enacting it. The theory of ideology, thus enriched and elaborated through a reflection on language, enriches in turn our view of language. For it directs our attention towards aspects of language use which have been neglected or suppressed by some perspectives in linguistics and the philosophy of language. To explore the interrelations between language and ideology is to turn away from the analysis of well-formed sentences or systems of signs, focusing instead on the ways in which expressions serve as a means of action and interaction, a medium through which history is produced and society reproduced. The theory of ideology invites us to see that language is not simply a structure which can be employed for communication or entertainment, but a social historical phenomenon which is embroiled in human conflict." [11]

Then, to categorize ideologies found in these fairy tales, categorization of ideology was used. This categorization is divided into three, namely hegemonic or dominant ideology, residual ideology, and emergent ideology. Hegemonic ideology is selective and tends to marginalize and suppress other ideological practices, which take place in the process of conflict. Residual ideology is an ideology that was formed in the past that continues to be practiced up to the present, or can be said that it is an ideology that is trying to maintain its existence. Meanwhile, emergent ideology is an ideology that substantively contradicts the dominant ideology, or it can be said that it is an ideology which is trying to usurp hegemony [12].

\section{Results and Discussion}

The results of Japanese fairy tales Kaguyahime and Tsuru no Ongaeshi's analysis are divided into two parts, namely identification of ideology and categorization of ideology. 


\subsection{Identification of Ideology}

In both tales, ideology of patriarchism and feminism that appear to be contradicted has found. The explanations are as follows.

\subsubsection{Ideology of Patriarchism}

According to Barker, patriarchy refers to a social order in which men dominate subordinated women, as in the following quote.

"The idea of patriarchy refers to a social order in which there is recurrent and systematic domination of men over subordinated women across a wide range of social institutions and practices. The term, which is connected to feminist theory and gained currency during the second wave of the women's movement dating from the 1960s, clearly carries the connotations of the male-headed family, mastery and superiority. As such, the concept of patriarchy asserts that sex is a central organizing principle of social life where gender relations are thoroughly saturated with power." [10]

This ideology states that men have a higher position than women, that women must always be controlled by men, and that women are part of men's property.

In their research on gender representation in Japanese folklore, Ariefa and Mutiawanthi concluded that in relation to position of men in the family, men have full authority in making decisions for all family members. Meanwhile, women are the household administrators who are obliged to devote themselves to men in the family as part of decency values [7]. Furthermore, Ariefa and Mutiawanthi stated that women engage in domestic activities such as weaving, cooking, cleaning the house, and raising children.

Based on the description of the ideology of patriarchism and its characteristics, it can be said that this form of ideology in Kaguyahime has emerged from the beginning of the story, when tiny Princess Kaguya was found inside a glowing bamboo tree by an old man. The old man, who live with his wife only, then decided to take care of and raise Princess Kaguya. This event represented the old man's higher position compared to Princess Kaguya who had been saved and taken care by the old man. Also higher compared to the old man's wife. The following quotation explain this.

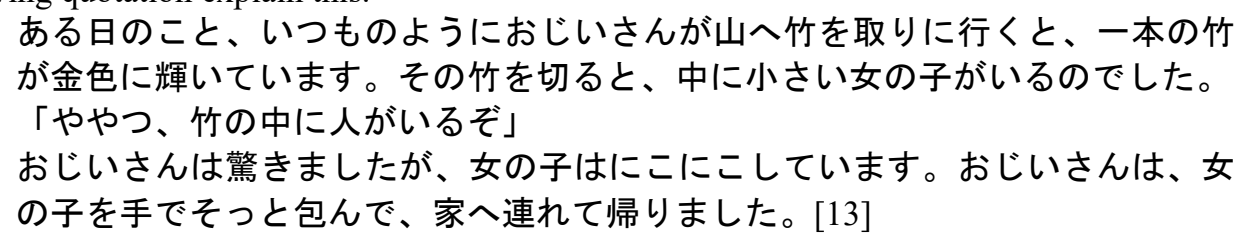

One day, when a bamboo seeker old man went to the mountain to seek bamboo as he usually do, he saw one bamboo tree that glows with golden light. The old man then cut that glowing bamboo, and he found a very tiny little girl inside that bamboo.

"Uh oh, this bamboo has a little girl inside it."

The old man was surprised, but the tiny little girl is smiling. The old man then softly wrapped that tiny little girl in his hand and took her home.

After three months passed, Princess Kaguya miraculously grew up very quickly and became a very beautiful young woman. News of Princess Kaguya's unequaled beauty has spread to the capital. This news has made many men flock to the old man's house to marry her. かぐや姫は、誰も見たことがないほど美しく、その名前は、すぐに都にも知れ 渡りました。お金持ちや身分の高い貴族など大勢の男達が、かぐや姫を妻にし たいと、やってくるようになったのです。 
結婚を申し込もうと、屋敷の周りには男達が列をなし、かぐや姫に会おうとし ます。中には垣根や門の隙間から、一目でもかぐや姫を見ようとして、誢き込 む男もいるほどでした。[13]

Princess Kaguya is so beautiful that no one has ever seen such beauty, and her name quickly became well known in the capital. Many men, including wealthy and highranking noblemen, flock to the old man's house to marry Princess Kaguya.

In order to propose Princess Kaguya for marriage, those men gathered around the house and try to see her. Some men peeked through gaps between fences and gate to looked inside the house to see Princess Kaguya, even just for a glance.

The above quotation shows that men see women as nothing more than objects that are part of their property, regardless of those women's self and privacy. This is one of the characteristics of patriarchism.

The higher position of men compared to women is also one of the characteristics of patriarchism. In addition, women are portrayed as figures who tend to have no courage nor freedom to freely express their opinions and personal feelings [7]. This difference in position makes men may act at their will to women, but not vice versa. Women's inability to freely express their feelings has made Princess Kaguya not directly reject the proposes of men who want to marry her, but by proposing conditions that are very difficult to anyone to fulfill it, as the following quotation shows.

「それでは私が欲しいものを持ってきてくれた方のところに、嫁ぐことにしま しょう」

かぐや姫はそう言って、五人にそれぞれ持ってきて欲しいものを伝えました。 「う一む、どれも難しい」

五人とも頭をかかえて、どうしたものかと考えました。[13]

"I wish to marry someone who can bring me what I want."

After Princess Kaguya said that, she told them things she wanted them to bring.

"Hmmm, all of them are hard to find."

The five men were holding their heads and thinking hard.

Like the Kaguyahime fairy tale, Tsuru no Ongaeshi fairy tale has also led to the ideology of patriarchism since the beginning of the story. The old man who freed the crane who was caught in the trap of a hunter seemed to have a higher position, considering that the crane later became a woman to return her favor to the old man. The following is the quotation when the old man frees the crane from trap.

ある日、おじいさんが山でたきぎを拾っていると、ワナにかかって苦しんでい る一羽のツルを見つけました。 おじいさんが、かわいそうに思ってワナから逃がしてやると、ツルは、うれし そうに空高く飛んでゆきました。[14]

One day, when an old man was looking for firewood on the mountain, he saw a crane that was in pain because of being caught in a trap.

The old man felt sorry for the crane and then released her. The crane then flew high into the sky.

Like Princess Kaguya, the exploitation of woman was also experienced by young female character who is an incarnation of a crane in the Tsuru no Ongaeshi fairy tale. In this fairy tale, the crane pulled out its feathers and then weaved it into beautiful fabrics for the old man, as a return of his favor. This seems to imply that women must be willing to do anything for men as a form of self-service, even if it hurts themselves like what quotation below shows. 
それから、娘は毎日はた織りを続け、できた反物は高い値段で売れ、たちまち 評判となりました。しかし、ふしぎなことに娘は日に日にやせていくのです。 「もう、はた織りはやめなさい」

見かねたおじいさんとおばあさんが止めると、娘は「これを最後にします」と 言い、また部屋の中に入りました。

しかし、おじいさんとおばあさんは心配のあまり、娘に言われたことを忘れ、 とうとう部屋の中をのぞいてしまいました。二人はおどろきました！！

一羽のツルがはた織りをしていたのです。自分の羽を抜いて布に織り込んでい ます。もうたくさんの羽を抜いてきたのでしょう。ツルは、すっかり弱ってい ました。[14]

Then, the young woman continued to weave every day. Her woven fabrics sold at high prices, so they quickly became popular. But strangely, the young woman's body got thinner and thinner.

"Please, stop weaving."

Said the old man and his wife to the young woman in the room, so they could not see what she was doing. But the young woman came out of her room and said, "This will be the last", then she went back into her room.

However, because they were very worried, the old man and his wife forgot what the young woman said to them. They peeked into her room. The two of them got very surprised!!

They saw a crane bird weaving some fabric. The crane pulled out its feathers and then weaved it into a fabric. By looking at the crane, many feathers have been pulled out for sure. The crane looked really weak.

\subsubsection{Ideology of Feminism}

Quoting Ratna's statement, feminism is considerably a concept that rejects everything that is marginalized, subordinated, and demeaned by the dominant group in various aspects of life [2]. In this case, feminism is a mean for women to fight for their rights in society that related to conflicts of sex, class and race, especially gender conflicts. On the other hand, Fakih stated that feminism is not an attempt of women rebel against men, nor some effort to fight household social institutions, marriage, or to deny the nature of women. However, feminism is an attempt conducted by women to end oppression and exploitation of themselves and others. Therefore, feminism actually does not only highlight sex or gender issues, but also targets humanitarian issues or a fight for human rights [15].

In Kaguyahime fairy tale, the ideology of feminism was shown by Princess Kaguya when men flocked to the old man's house to marry her. Even though in the end she came out of her room to meet those men, but she gave a very hard to fulfill condition for anyone who wanted to marry her. This shows Princess Kaguya's efforts to fight the exploits of the men against her.

「それでは私が欲しいものを持ってきてくれた方のところに、嫁ぐことにしま しょう」

かぐや姫はそう言って、五人にそれぞれ持ってきて欲しいものを伝えました。 「う一む、どれも難しい」

五人とも頭をかかえて、どうしたものかと考えました。[13]

"I wish to marry someone who can bring me what I want."

After Princess Kaguya said that, she told them things she wanted them to bring.

"Hmmm, all of them are hard to find." 
The five men were holding their heads and thinking hard.

Even though indirectly and in a polite manner, Princess Kaguya dared to reject the marriage proposal from all of those wealthy and noble men. She even dared to reject the Emperor's marriage proposal. This event confirms Princess Kaguya's resistance to exploitation of herself as a woman.

帝は、それからも何回も人を使わして、かぐや姫を仕えさせようとしましたが、 「おじいさんとおばあさんの近くにいたいのです」

と言って、首を縰には降りませんでした。[13]

Although the Emperor has repeatedly stated that he is willing to provide what Princess Kaguya wants through his servants, Princess Kaguya still doesn't show her agreement. Instead, she says,

"I want to stay close to Grandfather and Grandmother."

In Tsuru no Ongaeshi fairy tale, the ideology of feminism was discovered when the crane decided to leave the old man and his wife, even though they asked her to stay. The crane firmly stated that she could not stay with the old man and his wife anymore, unlike Princess Kaguya who expressed her desire not to marry indirectly. The crane left the old man and his wife after they learned that the young woman who had been weaving beautiful fabrics for them were the incarnation of the crane that the old man once helped.

「わたしは、命を助けていただいたツルです。恩返しにまいりました。でも、 正体を知られた以上、もうここに入りことはできません」

ツルは、空に舞い上がりました。

「待っておくれ、行かないでおくれ!」

おじいさんとおばあさんはさけびながら、ツルが飛んで行った空のかなたを見

つめていました。[14]

"I am the crane you've saved. I'm here to return the favor. But, because now the two of you know what I really am, I can't stay here anymore."

The crane then flew high into the sky.

"Wait, don't go!"

Shout the old man and his wife. They could only look at the crane which had flown away.

\subsection{Categorization of Ideology}

In Kaguyahime and Tsuru no Ongaeshi fairy tales, two ideologies that influenced and moved the characters in these tales were found, namely the ideology of patriarchism and feminism. Although only two ideologies in these fairy tales were found, the two emerging ideologies can be categorized as hegemonic ideology, residual ideology and emergent ideology.

\subsubsection{Hegemonic Ideology}

As mentioned earlier, hegemonic ideology is selective and tends to marginalize and suppress other ideological practices. Based on these criteria, the ideology of patriarchism is categorized as a hegemonic ideology in the Kaguyahime and Tsuru no Ongaeshi fairy tales. Even though ideology of feminism is also found in these tales, which is contrary to patriarchism, it was only emerged in one event in each tale, so it does not have a significant influence on patriarchal dominance in these two fairy tales.

One example is when the Emperor tried to protect Princess Kaguya who would be forcibly picked up by the lunarians to return to the moon, because Princess Kaguya actually still wanted to 
continue living with the old man and his wife. This event shows that a man (Emperor) is described as a strong (protective) person, while a woman (Princess Kaguya) is a weak person (need to be protected). Likewise with what happened in the Tsuru no Ongaeshi fairy tale. The old (elderly) man was able to protect the crane which later transformed into a woman.

Aside from being described as a strong figure, men are also described as rational in patriarchal ideology, contrary to the emotional female figure. This appears in the incident when Princess Kaguya felt compelled to return to the moon because actually she wanted to continue living with the old man and his wife, without any other logical reason. On the other hand, the Emperor prepared his troops to guard Princess Kaguya so that she can not forcibly picked up by lunarian to go back to the moon, even though the Emperor and his troops failed. Likewise with the crane who plucked her feathers to be woven into fabrics for the old man who have saved her as a return of the favor, until her body got thinner and weak.

Hegemony of patriarchal ideology is directly proportional to gender hegemony which identifies women with domestic activities. This can be seen in the types of women's activities in both tales. The crane and the two old men's wives, all of whom were shown doing domestic activities such as cooking and weaving. Furthermore, Princess Kaguya did not show any activities other than sitting, daydreaming, and receiving guests. As a part of men's property in patriarchal ideology, her task is simply to sit downs and looks beautiful.

Ideologies that have become so dominant in society and become hegemonic do not spread by themselves. The spreading of ideology is carried out through certain social institutions. The responsibility in spreading ideology lies within intellectuals who are classified into organic intellectuals and traditional intellectuals. Organic intellectuals acted as dominant class functionaries in spreading ideology in order to become hegemonic. Meanwhile, traditional intellectuals refer to intellectual categories that already exist in society as part of their historical continuity (Al Hafizh et al., 2017: 144). In relation to Kaguyahime and Tsuru no Ongaeshi fairy tales, acting as organic intellectuals are ordinary people who tell the two stories from generation to generation. Meanwhile, educators and educated groups who are in formal institutions become part of traditional intellectuals, considering that they also participated in spreading these fairy tales formally and informally.

\subsubsection{Residual Ideology}

The ideology of patriarchism can also be categorized into residual ideology, because the ideology of patriarchy refers to experiences, meanings and values formed in the past that continue to live and be practiced in the present. It can be said that the ideology of patriarchism struggles to maintain its existence. This can be seen from the ideology of feminism that is slow but surely trying to compete with patriarchal ideology which has become a hegemony in society. The incidents when Princess Kaguya and the crane reject something that they do not want became evidences that women tried to voice their opinions and desires.

\subsubsection{Emergent Ideology}

The ideology of feminism in these fairy tales included in emergent ideology because feminism was in accordance with the characteristic of emergent ideology, which substantively contradicted hegemonic ideology. It can be said that feminism is an ideology that is trying to usurp the hegemony that has been dominated by patriarchism. This can be seen from the incidents when Princess Kaguya reject the wealthy men's, the noble men's and the Emperor's marriage proposals. When the crane departs from the old man and his wife's house also showed the same thing. These two incidents are evidences that women try to voice their opinions and desires. 


\section{Conclusion}

As an example of classic Japanese fairy tales, Kaguyahime and Tsuru no Ongaeshi reflect that the ideology of patriarchism and feminism have lived side by side in Japan for a long time. Nevertheless, it cannot be denied that patriarchal and gender hegemony still dominates Japanese society more than feminism. Patriarchism which is categorized as a hegemonic and residual ideology seem to be trying to maintain its dominance in society amid the stretch of feminism as an emergent ideology that seeks to compete with patriarchism to usurp hegemony in Japanese society.

\section{Acknowledgement}

This article is a part of research output which was supported by Faculty of Humanities, Diponegoro University's DIPA Fund 2019 fiscal year. Therefore, I would like to thank the Dean of Faculty of Humanities, Diponegoro University.

\section{References}

[1] R. G. Collingwood, The Philosophy of Enchantment: Studies of Folktale, Cultural Criticism, and Anthropology. Oxford: Oxford University Press, 2005.

[2] N. K. Ratna, Teori, Metode, dan Teknik Penelitian Sastra. Yogyakarta: Pustaka Pelajar, 2008.

[3] M. Holmes, What is Gender? : Sociological Approaches. London: SAGE Publications Ltd., 2007.

[4] A. Gramsci, Selection from the Prison Notebooks. New York: International Publisher, 1971.

[5] A. Zamzuri, "Ideologi dalam Novel Pabrik Karya Putu Wijaya," Atavisme, vol. 20, no. 1, p. 14, 2017.

[6] M. Al Hafizh, F. Faruk, and J. Juliasih, "Identifikasi Ideologi dan Pola Relasinya dalam Novel-Novel Jacqueline Woodson," Atavisme, vol. 19, no. 2, p. 130, 2017.

[7] N. A. Ariefa and M. Mutiawanthi, "Representasi Gender Dalam Folklor Jepang," J. Al-AZHAR Indones. SERI Hum., vol. 3, no. 3, pp. 261-273, 2017.

[8] Faruk, Pengantar Sosiologi Sastra. Yogyakarta: Pustaka Pelajar, 1994.

[9] J. Francese, Perspectives on Gramsci: Politics, Culture and Social Theory. Oxon: Routledge, 2009.

[10] C. Barker, The SAGE Dictionary of Cultural Studies. London: SAGE Publications Ltd., 2004.

[11] J. B. Thompson, Studies in the Theory of Ideology. Berkeley: University of California Press, 1984.

[12] R. Williams, Marxism and Literature. New York: Oxford University Press, 1977.

[13] Y. Tanimoto, "Nihon no Mukashibanashi : Kaguyahime," Pictio Co., Ltd., 2014. [Online]. Available: http://www.pictio.co.jp/old/4451 kaguyahime.

[14] T. Kuwahara, "Tsuru no On'gaeshi," City Plan Co., Ltd., 2013. [Online]. Available: http://www.e-douwa.com/japan/grateful-crane/.

[15] Sugihastuti and Suharto, Kritik Sastra Feminis : Teori dan Aplikasinya. Yogyakarta: Pustaka Pelajar, 2002. 